CZASOPISMO INŻYNIERII LĄDOWEJ, ŚRODOWISKA I ARCHITEKTURY JOURNAL OF CIVIL ENGINEERING, ENVIRONMENT AND ARCHITECTURE

JCEEA, t. XXXIV, z. 64 (1/17), styczeń-marzec 2017, s. 377-393, DOI:10.7862/rb.2017.35

\author{
Marta WÓJCIK ${ }^{1}$ \\ Feliks STACHOWICZ ${ }^{2}$ \\ Adam MASŁON ${ }^{3}$
}

\title{
MOŻLIWOŚĆ WYKORZYSTANIA POPIOŁÓW LOTNYCH W CELU POPRAWY ODWADNIANIA OSADÓW ŚCIEKOWYCH
}

\begin{abstract}
Wzrost zapotrzebowania na energię wiąże się ze spalaniem paliw i tym samym wytwarzaniem coraz większej ilości ubocznych produktów spalania (UPS), w tym popiołów lotnych. Rocznie w Polsce powstaje około 4,2 mln ton popiołu, z czego tylko niewielką część poddaje się procesowi recyklingu (zwłaszcza w sektorze budowlanym). Ograniczenia dotyczące komercyjnego wykorzystania popiołów wymagają poszukiwania nowych metod ich zagospodarowania, korzystnych pod względem ekologicznym, ekonomicznym oraz prawnym. Specyficzne właściwości fizykochemiczne umożliwiają zastosowanie popiołów jako substancji kondycjonującej osady ściekowe przed procesem odwadniania. Prezentowana praca zawiera studium literatury dotyczącej właściwości oraz wpływu popiołów lotnych ze spalania różnych paliw na stopień odwodnienia i skład mikrobiologiczny osadów ściekowych. W artykule przedstawiono również korzyści ekonomiczne związane z zastosowaniem popiołów w procesach przeróbki osadów ściekowych. Zastosowanie ubocznych produktów spalania paliw w oczyszczalniach ścieków stanowi nowe zagadnienie w zakresie gospodarki osadami ściekowymi.
\end{abstract}

Słowa kluczowe: osady ściekowe, popioły lotne, odwadnianie, kondycjonowanie, odzysk, utylizacja, gospodarka osadami ściekowymi

\section{Wprowadzenie}

Popioły lotne są odpadami energetycznymi, powstającymi w wyniku spalania surowców energetycznych w elektrociepłowniach. Stanowią uboczny produkt spalania, wychwytywany ze spalin za pomocą urządzeń odpylających, umieszczonych za komorą spalania. Zgodnie z Rozporządzeniem Ministra Śro-

${ }^{1}$ Autor do korespondencji / corresponding author: Marta Wójcik, Politechnika Rzeszowska, Katedra Przeróbki Plastycznej, al. Powstańców Warszawy 8, 35-959 Rzeszów; tel. 178651507; e-mail: m.wojcik@prz.edu.pl

${ }^{2}$ Feliks Stachowicz, Politechnika Rzeszowska, Katedra Przeróbki Plastycznej, al. Powstańców Warszawy 8, 35-959 Rzeszów; tel. 178651538; e-mail: stafel@ prz.edu.pl

3 Adam Masłoń, Politechnika Rzeszowska, Zakład Inżynierii i Chemii Środowiska, al. Powstańców Warszawy 6, 35-959 Rzeszów; tel. 177432407; e-mail: amaslon@ @rz.edu.pl 
dowiska z dnia 9 grudnia 2014 r. w sprawie katalogu odpadów [33], popioły lotne ze spalania węgla klasyfikuje się kodem 1001 02: popioły lotne z węgla lub w przypadku współspalania węgla z biomasą-10 01 17: popioły lotne ze współspalania inne niż w 1001 16. Popioły lotne ze spalania czystej biomasy drzewnej zgodnie ze wspomnianym rozporządzeniem posiadają kod odpadów 1001 03: popioły lotne z torfu i drewna niepoddanego obróbce chemicznej [33].

W związku ze wzrastającym zapotrzebowaniem na energię oraz powstawaniem nowych zakładów i instalacji, ilość odpadów wytwarzanych w wyniku termicznego przekształcania paliw ciągle wzrasta. Światowa produkcja popiołów lotnych szacowana jest na około 4,2 mld ton rocznie, z czego najwięcej produkuje się w Chinach i Stanach Zjednoczonych [9]. W Polsce co roku powstaje około 4,2 mln ton popiołu lotnego, przy czym zaledwie $4 \div 9 \%$ poddaje się wykorzystaniu [34].

W zależności od rodzaju spalanego paliwa oraz właściwości fizykochemicznych ubocznych produktów spalania (UPS), popioły podlegają procesom składowania lub recyklingu. Obecnie, obserwuje się wzrost odzysku popiołów lotnych ze spalania węgla w wielu krajach, zwłaszcza w wysoko rozwiniętych, co wynika głównie z ich zastosowania w sektorze budowlanym. Należy jednak podkreślić, że komercyjne przeznaczenie popiołów jest bardzo ograniczone ze względu na rygorystyczne normy w zakresie ich właściwości fizycznych i składu chemicznego. Niemniej jednak, popiół lotny ze spalania paliw kopalnych znalazł zastosowanie jako dodatek do produkcji cementu, wypełniacz strukturalny przy budowie dróg oraz wałów przy autostradach. Popioły lotne mogą być również z powodzeniem wykorzystywane w innych dziedzinach gospodarki, $\mathrm{w}$ tym również $\mathrm{w}$ rolnictwie. Wyniki badań przeprowadzonych przez Kincannona [16] potwierdziły skuteczność stosowania preparatu wytworzonego z osadów ściekowych i popiołu lotnego w procesie kondycjonowania gleb.

O ile popioły lotne ze spalania węgla kamiennego i brunatnego mogą znaleźć zastosowanie w branży drogowej oraz cementowej, dużym problemem w dziedzinie gospodarki odpadami jest zapewnienie odpowiedniego pod względem prawnym i ekologicznym zagospodarowania popiołów ze spalania biomasy. Ograniczenia związane $\mathrm{z}$ recyklingiem popiołów wynikają $\mathrm{w}$ dużej mierze z obowiązujących przepisów prawnych, które nie regulują kwestii biomasy (problem klasyfikacji odpadów), co uniemożliwia ich zastosowanie w wielu dziedzinach gospodarki. Popioły powstające w wyniku termicznego przekształcania biomasy mogłyby być skutecznie stosowane w rolnictwie lub do budowy obwałowań składowisk odpadów, bez stwarzania ryzyka zagrożenia dla poszczególnych komponentów środowiska [27].

Problem związany z nadmierną ilością popiołów lotnych oraz osadów ściekowych wymaga opracowania racjonalnych rozwiązań, umożliwiających ich zagospodarowanie zgodnie z zasadami ochrony środowiska. Z punktu widzenia gospodarki odpadami, najlepszym sposobem na zmniejszenie ilości powstających frakcji odpadów jest zastosowanie mieszaniny osadów ściekowych i popiołu do aplikacji doglebowej, co zapewnia ich jednoczesne zagospodarowanie. 


\section{Charakterystyka fizykochemiczna popiołów lotnych}

Właściwości popiołów lotnych zależą od rodzaju spalanego paliwa (węgiel kamienny, węgiel brunatny, biomasa) oraz zastosowanej technologii procesu spalania (w kotłach z paleniskiem konwencjonalnym lub ze złożem fluidalnym) [34]. Przykładowy schemat budowy kulistej cząstki popiołu lotnego został zaproponowany przez Dudasa i Warrena [6] (rys.1). Według przedstawionego modelu cząstka popiołu lotnego zbudowana jest $\mathrm{z}$ wewnętrznej szklanej matrycy oraz kryształków igiełkowych mullitu osadzonych w warstwie przypowierzchniowej szkła. Niekiedy ziarna mullitu stanowią inkluzje wewnątrz sferycznych ziaren szkła. Na powierzchni ziarna znajdują się również drobne kryształy minerałów popiołu lotnego. Przyjmuje się, że powierzchnia cząstek popiołu lotnego pokryta jest cienką warstwą elektrostatycznie osadzonego pyłu grafitowego [6].

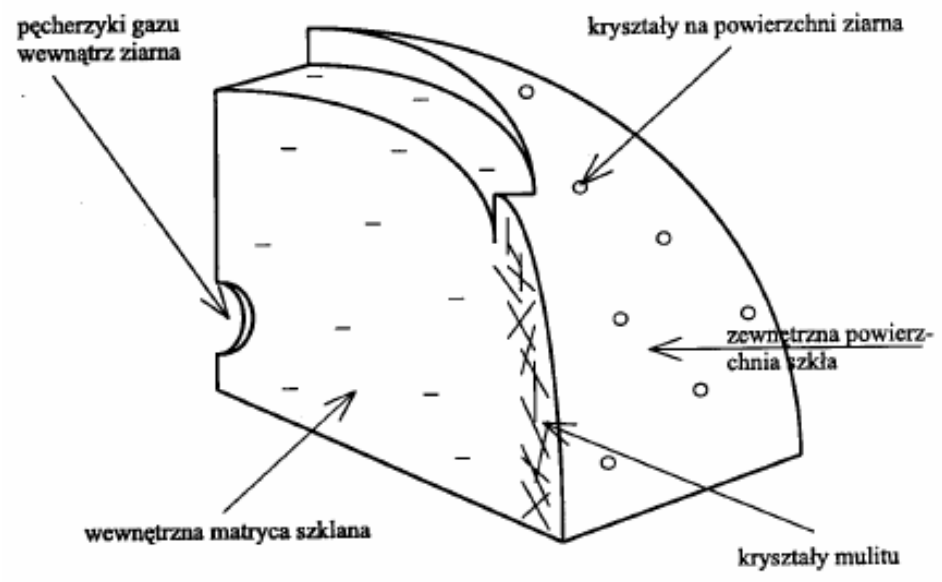

Rys. 1. Model budowy kulistej cząstki popiołu lotnego, według Dudasa i Warrena [6]

Fig. 1. Model of the spherical ash particle according to Dudas and Warren [6]

Wszystkie popioły lotne są materiałami pylistymi barwy od jasnoszarej do czarnej i brązowej [32]. Popiół lotny wykazuje bardzo niejednorodny rozkład uziarnienia, co wynika $\mathrm{z}$ rodzaju spalanego węgla oraz typu kotła użytego $\mathrm{w}$ procesie spalania. Ziarna popiołu powstałego $\mathrm{w}$ konwencjonalnych kotłach mają kształt kulisty o wielkości cząstek w zakresie $0,01 \div 350 \mu \mathrm{m}$, natomiast popioły lotne z kotłów fluidalnych są cząstkami o bardzo nieregularnych kształtach i wydłużonych krawędziach w rozmiarze zwykle nie przekraczającym $100 \mu \mathrm{m}$ (rys.2) [2, 5]. Gęstość popiołu lotnego zawiera się w przedziale $1900 \div 2800 \mathrm{~kg} / \mathrm{m}^{3}$, przy czym najczęściej osiąga wartość $2000 \mathrm{~kg} / \mathrm{m}^{3}$ [4]. Charakterystyczną cechą popiołów lotnych jest obecność ziaren w postaci szklistych sfer tzw. mikrosfer. Z tego względu popioły lotne charakteryzują się dużą po- 
wierzchnią właściwą ( $2500 \div 6000 \mathrm{~m}^{2} / \mathrm{kg}$ ), zależną od stopnia zmielenia (im wyższy stopień zmielenia cząstek, tym większa gęstość i powierzchnia właściwa) oraz technologii spalania (większa powierzchnia popiołów z kotłów ze złożem fluidalnym) [20, 34].
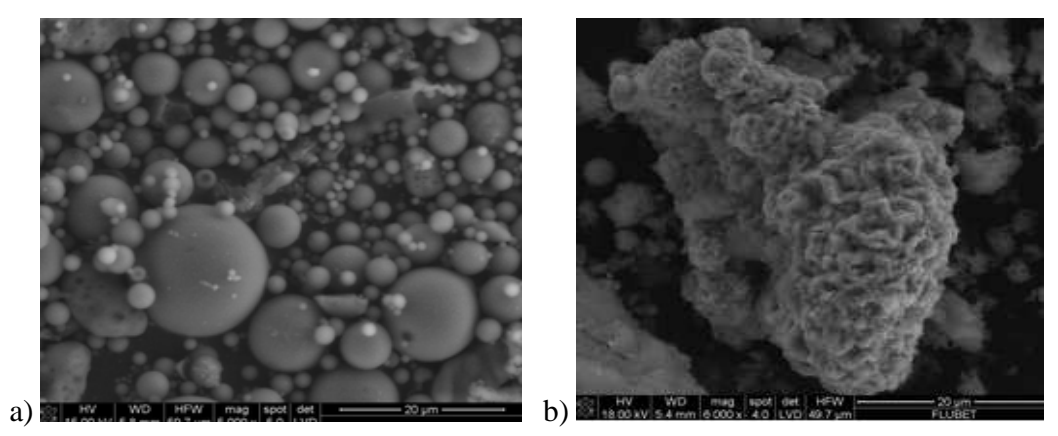

Rys. 2. Fotografia SEM popiołu lotnego z kotła konwencjonalnego (a) i kotła fluidalnego (b) [12]

Fig. 2. SEM images of fly ash from conventional boiler (a) and from fluidized-bed boiler (b) [12]

Część ziaren popiołu lotnego ( $1 \div 3 \%$ masy popiołów) występuje w postaci ziaren kulistych - tzw. mikrosfer (rys.3). Mikrosfery są lekką frakcją glinokrzemianów, powstającą podczas spalania węgla kamiennego w piecach pyłowych. Ziarna kuliste charakteryzują się mniejszą gęstością $\left(0,45 \div 0,6 \mathrm{~g} / \mathrm{m}^{3}\right)$ oraz niższym współczynnikiem przewodzenia ciepła. Specyficzna charakterystyka oraz właściwości mikrosfer umożliwiają ich szerokie wykorzystanie w budownictwie, hutnictwie oraz odlewnictwie. Niestety, w Polsce większość mikrosfer jest deponowana na składowiskach łącznie z popiołami [31].

a)
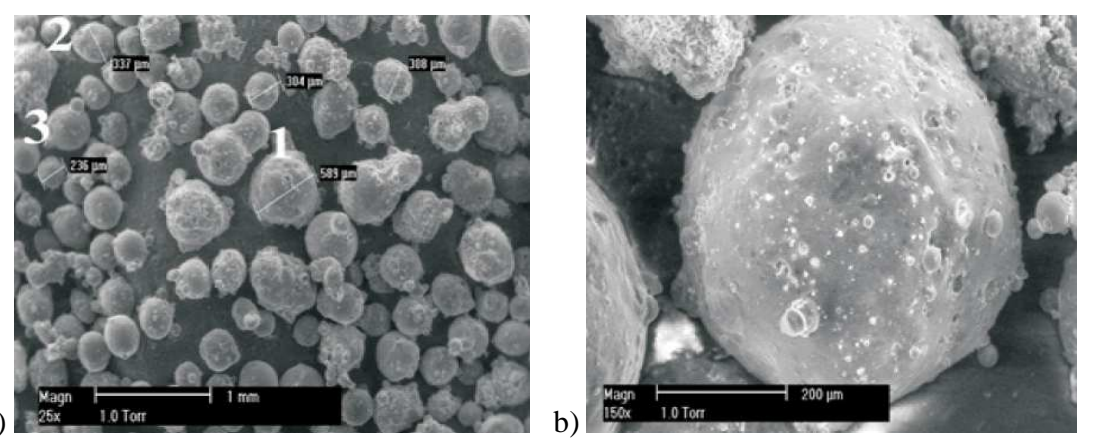

Rys. 3. Fotografia SEM mikrosfer (a) oraz pojedynczego ziarna (b) [13]

Fig. 3. SEM image of cenospheres (a) and the image of cenosphere particle (b) [13]

Odczyn popiołów lotnych zawiera się w przedziale od kwaśnego do zasadowego $(4,5 \div 12 \mathrm{pH})$ i zależy w dużym stopniu od zawartości siarki, zastosowa- 
nej technologii spalania oraz sposobu odsiarczania gazów. Charakter kwasowy lub zasadowy popiołów lotnych określa się zazwyczaj za pomocą wartości stosunku Ca:S. Popioły lotne o stosunku masowym Ca:S<2,5 wykazują charakter kwasowy, podczas gdy popioły lotne o wyższej wartości charakteryzują się odczynem zasadowym $[8,24]$. Skład chemiczny popiołu lotnego zbliżony jest do składu chemicznego substancji mineralnej spalanego węgla. Głównymi związkami chemicznymi $(95 \div 99 \%)$ zawartymi w popiołach są: $\mathrm{SiO}_{2}, \mathrm{Al}_{2} \mathrm{O}_{3}, \mathrm{FeO}_{3}$ oraz $\mathrm{CaO}$ (tabela 1). Biorąc pod uwagę stosunek zawartości składników kwasowych $\left(\mathrm{SiO}_{2}, \mathrm{Al}_{2} \mathrm{O}_{3}\right)$ do tlenków alkalicznych $\left(\mathrm{MgO}, \mathrm{CaO}\right.$ i $\left.\mathrm{Fe}_{2} \mathrm{O}_{3}\right)$, wyznacza się dla popiołów moduł tlenkowy, zgodnie ze wzorem (1):

$$
\frac{\mathrm{SiO}_{2}+\mathrm{Al}_{2} \mathrm{O}_{3}}{\mathrm{CaO}+\mathrm{MgO}+\mathrm{Fe}_{2} \mathrm{O}_{3}}
$$

Tabela 1. Skład tlenkowy popiołów lotnych ze spalania węgla na podstawie badań Koukouzas i wsp. [17]

Table 1. Chemical composition of coal fly ash in the oxide form according to Koukouzas et al. [17]

\begin{tabular}{|l|c|c|c|c|c|c|c|c|}
\hline \multirow{2}{*}{$\begin{array}{l}\text { Średnia zawar- } \\
\text { tość [\%] }\end{array}$} & $\mathrm{SiO}_{2}$ & $\mathbf{A l}_{2} \mathbf{O}_{\mathbf{3}}$ & $\mathbf{F e}_{2} \mathbf{O}_{3}$ & $\mathbf{M g O}$ & $\mathbf{C a O}$ & $\mathrm{Na}_{2} \mathbf{O}$ & $\mathbf{K}_{2} \mathbf{O}$ & $\mathbf{S O}_{3}$ \\
\cline { 2 - 9 } & $30,41 \pm$ & $17,02 \pm$ & $6,47 \pm$ & $3,24 \pm$ & $25,86 \pm$ & $1,75 \pm$ & $1,42 \pm$ & $9,61 \pm$ \\
& 1,864 & 0,3168 & 0,5615 & 0,4221 & 1,9474 & 0,3275 & 0,3071 & 0,9816 \\
\hline
\end{tabular}

Wartość wyznaczonego modułu tlenkowego popiołów lotnych pozwala dokonać ich klasyfikacji na krzemianowe (wartość $2 \div 6$ ), krzemianowo-glinowe (wartość $\leq 6$ ) i krzemianowo-węglanowe (wartość $\leq 2$ ) [30, 31]. Jako podrzędne składniki popiołu lotnego wymienia się najczęściej: $\mathrm{MgO}, \mathrm{Na}_{2} \mathrm{O}, \mathrm{K}_{2} \mathrm{O}, \mathrm{SO}_{3}$, $\mathrm{P}_{2} \mathrm{O}_{5}$ oraz $\mathrm{TiO}_{2}$. Wśród głównych pierwiastków występujących w popiołach lotnych, naukowcy najczęściej wymieniają: $\mathrm{Al}, \mathrm{Ca}, \mathrm{Mg}, \mathrm{K}, \mathrm{P}$ i S. Metale ciężkie, m.in. $\mathrm{Mn}, \mathrm{B}, \mathrm{Ba}, \mathrm{Cu}, \mathrm{Sr}, \mathrm{Ni}, \mathrm{Cr}, \mathrm{Zn}, \mathrm{Cd}, \mathrm{Co}$, Mo stanowią zaledwie $0,1 \div 0,3 \%$ masy popiołów, przy czym zawartość rtęci jest śladowa i zwykle mieści się w przedziale $0,01 \div 1 \mathrm{ppm}$ (tabela 2 ) $[6,16,17]$.

Ilość popiołów powstających w wyniku spalania biomasy jest ponad 10-krotnie mniejsza niż w przypadku spalania węgla. Odczyn popiołów ze spalania różnego rodzaju biomasy wykazuje charakter zasadowy i mieści się w zależności od rodzaju fitobiomasy w zakresie 9,3 $\div 13,9 \mathrm{pH}$. Również skład chemiczny popiołów ze spalania biomasy różni się od składu chemicznego popiołu ze spalania węgla. Popioły z biomasy roślinnej zawierają więcej $\mathrm{CaO}$, $\mathrm{K}_{2} \mathrm{O}$ oraz $\mathrm{P}_{2} \mathrm{O}_{5}$ i mniejszą ilość $\mathrm{SiO}_{2}$ oraz $\mathrm{Al}_{2} \mathrm{O}_{3}$ (tabela 3). Sporadycznie w popiołach mogą również występować podwyższone stężenia metali ciężkich w formach słabo rozpuszczalnych w wodzie [26]. 
Tabela 2. Skład chemiczny popiołów lotnych powstających podczas spalania węgla kamiennego na podstawie $[1,3,14,19,23,24,29,35]$

Table 2. Chemical composition of fly ash produced during the coal combustion based on $[1,3,14$, $19,23,24,29,35]$

\begin{tabular}{|c|c|c|c|c|c|c|c|c|}
\hline \multirow{2}{*}{$\begin{array}{c}\text { Pier- } \\
\text { wiastek }\end{array}$} & \multicolumn{8}{|c|}{ Zawartość pierwiastków w popiołach lotnych według różnych źródel } \\
\hline & $\begin{array}{c}\text { Page } \\
\text { i wsp. [23] }\end{array}$ & $\begin{array}{c}\text { Adriano } \\
\text { i wsp. [1] }\end{array}$ & $\begin{array}{c}\text { Jala i Go- } \\
\text { yal [14] }\end{array}$ & $\begin{array}{c}\text { Tripathi } \\
\text { [35] }\end{array}$ & $\begin{array}{c}\text { Pandey } \\
{[24]}\end{array}$ & $\begin{array}{c}\text { Riehl i } \\
\text { wsp. [29] }\end{array}$ & $\begin{array}{l}\text { Lopareva- } \\
\text { Pohu [19] }\end{array}$ & $\begin{array}{c}\text { Baliński } \\
{[3]}\end{array}$ \\
\hline \multicolumn{9}{|c|}{ Makroelementy [g/kg] } \\
\hline $\mathrm{Al}$ & $1 \div 17,3$ & - & 312,00 & - & 4,80 & 108,50 & 0,47 & 381,08 \\
\hline $\mathrm{Ca}$ & $1,1 \div 222$ & 5,40 & 34,00 & 0,029 & - & 86,40 & 1,84 & 30,66 \\
\hline $\mathrm{Fe}$ & $10 \div 290$ & 16,00 & 68,00 & 0,0032 & 4,00 & 36,60 & 0,31 & 30,62 \\
\hline $\mathrm{K}$ & $1,5 \div 35$ & 1,80 & 10,80 & 0,072 & - & 24,50 & 0,0021 & 3,33 \\
\hline $\mathrm{Mg}$ & $0,4 \div 76$ & 1,20 & 1,40 & 0,017 & - & 11,50 & 0,019 & 9,46 \\
\hline $\mathrm{P}$ & $0,4 \div 8$ & 0,50 & 10,80 & 0,0027 & 1,10 & 2,10 & 0,0024 & 1,11 \\
\hline$S$ & $1 \div 15$ & 20,00 & 0,02 & 0,058 & - & 2,00 & 0,013 & 1,12 \\
\hline \multicolumn{9}{|c|}{ Mikroelementy $[\mathrm{g} / \mathrm{kg}]$} \\
\hline As & $2,3 \div 6300$ & - & 6,20 & - & - & - & 20,40 & 0,006 \\
\hline B & $10 \div 618$ & 50,00 & - & - & 28,90 & - & 0,40 & - \\
\hline $\mathrm{Cd}$ & $0,7 \div 130$ & 1,30 & 1,90 & 13,40 & 42,50 & 0,03 & - & 0,02 \\
\hline $\mathrm{Co}$ & $7 \div 520$ & 7,00 & 58,00 & 21,10 & - & 26,00 & 17,00 & - \\
\hline $\mathrm{Cr}$ & $10 \div 1000$ & 15,00 & 330,00 & 38,20 & 40,30 & 148,00 & 46,00 & 6,00 \\
\hline $\mathrm{Cu}$ & $14 \div 2800$ & 19,00 & 0,002 & 65,80 & 58,40 & 57,00 & 38,00 & - \\
\hline $\mathrm{Hg}$ & $0,02 \div 1,0$ & 0,18 & - & - & - & - & 0,40 & - \\
\hline $\mathrm{Mn}$ & $58 \div 3000$ & 100,00 & 739,00 & 0,006 & 69,30 & 679,00 & 418,00 & - \\
\hline Mo & $7 \div 160$ & 3,00 & 4,00 & - & 33,30 & 4,20 & - & - \\
\hline $\mathrm{Ni}$ & $6,3 \div 4300$ & 15,00 & 13,00 & 44,20 & 204,80 & 88,00 & 48,00 & - \\
\hline $\mathrm{Pb}$ & $3,1 \div 5000$ & 16,00 & 35,00 & 20,00 & 40,20 & 97,00 & 39,00 & 7,00 \\
\hline $\mathrm{V}$ & - & 20,00 & - & - & - & 182,00 & - & - \\
\hline $\mathrm{Se}$ & $0,2 \div 134$ & 3,00 & 3,60 & - & - & - & - & - \\
\hline $\mathrm{Zn}$ & $10 \div 3500$ & 39,00 & 79,00 & 57,70 & 82,30 & 167,00 & 85,00 & 8,00 \\
\hline
\end{tabular}

Tabela 3. Skład chemiczny popiołów z biomasy na podstawie [26, 38]

Table 3. Chemical composition of biomass ashes based on [26, 38]

\begin{tabular}{|c|c|c|c|c|c|c|c|c|c|c|}
\hline \multirow{2}{*}{$\begin{array}{c}\text { Rodzaj } \\
\text { biomasy }\end{array}$} & \multicolumn{10}{|c|}{ Zawartość związków chemicznych [\%] } \\
\hline & $\mathrm{SiO}_{2}$ & $\mathrm{Al}_{2} \mathrm{O}_{3}$ & $\mathrm{Fe}_{2} \mathrm{O}_{3}$ & $\mathrm{CaO}$ & MgO & $\mathrm{Na}_{2} \mathrm{O}$ & $\mathbf{K}_{2} \mathbf{O}$ & $\mathrm{P}_{2} \mathrm{O}_{5}$ & $\mathrm{SO}_{3}$ & $\mathrm{Mn}_{3} \mathrm{O}_{4}$ \\
\hline zrębki wierzby & 18,97 & 3,52 & 2,09 & 44,50 & 3,93 & 0,58 & 8,51 & 5,90 & 3,15 & 0,11 \\
\hline zrębki s & 28,25 & 0 & 5,02 & 36,54 & 8,15 & 1,20 & 6,26 & 0,65 & 0,58 & 0,20 \\
\hline $\begin{array}{l}\text { zrębki z } \\
\text { na bukou }\end{array}$ & 30,47 & 3,63 & 2,14 & 29,60 & 3,67 & 0,35 & 10,27 & 2,68 & 1,71 & 2,13 \\
\hline \begin{tabular}{|l} 
pellet \\
z siana \\
\end{tabular} & - & - & - & 18,80 & 2,70 & - & 10,40 & 4,30 & - & - \\
\hline ziarno owsa & - & - & - & 3,50 & 4,50 & - & 14,80 & 11,80 & - & - \\
\hline zrębki dębu & - & - & - & 40,30 & 3,50 & 0,50 & 9,40 & 2,20 & - & - \\
\hline słoma jara & 7,20 & 0,58 & 0,53 & 7,40 & 3,40 & 0,58 & 6,50 & 3,60 & 4,52 & 0,06 \\
\hline
\end{tabular}


Wymywalność składników rozpuszczalnych z popiołów zależy od rodzaju spalanego paliwa (węgiel, biomasa) oraz zastosowanej technologii spalania (kotły konwencjonalne lub ze złożem fluidalnym). Popioły ze spalania paliwa w kotłach konwencjonalnych wykazują niższą wymywalność jonów niż w przypadku zastosowania technologii fluidalnej. Badania wymywalności różnych pierwiastków dla popiołów lotnych z: węgla kamiennego, węgla brunatnego oraz biomasy zostały przeprowadzone przez Uliasz-Bocheńczuk (tabela 4) [36]. Wyniki badań wykazały bardzo wysoką wymywalność jonów potasu, chloru, chromu oraz siarczanów z popiołów ze spalania biomasy w porównaniu do popiołów z węgla kamiennego [36].

Wymywalność pierwiastków z popiołów ze spalania biomasy można uszeregować następująco: $\mathrm{Cl}>\mathrm{S}>\mathrm{K}>\mathrm{Na}>\mathrm{Sr}>\mathrm{Ni}>\mathrm{Mn}>\mathrm{Cd}>\mathrm{Kr}>\mathrm{Zn}>\mathrm{Co}>$ $\mathrm{Si}>\mathrm{Mo}>\mathrm{Li}>(\mathrm{Mg}, \mathrm{Pb})>\mathrm{Ca}>>\mathrm{Cu}>\mathrm{Ba}>\mathrm{P}>\mathrm{Se}>\mathrm{Sb}>\mathrm{Al}>\mathrm{Fe}>(\mathrm{Br}, \mathrm{Hg})$ $>(\mathrm{W}, \mathrm{B}, \mathrm{Sn}, \mathrm{Ti}, \mathrm{V})$. Wysoka wymywalność substancji rozpuszczonych z popiołów otrzymywanych ze spalania biomasy wynika $\mathrm{z}$ występowania w popiołach łatwo rozpuszczalnych chlorków (sylwit, halit), siarczanów (syngenit, ettringit, gips), tlenków $(\mathrm{CaO})$, wodorotlenków (portlandyt), azotanów, węglanów i wodorowęglanów. Duża wymywalność takich pierwiastków jak $\mathrm{Ba}, \mathrm{Cl}, \mathrm{Cr}$, Mo i $\mathrm{Pb}$ może stanowić poważny problem, ograniczający zagospodarowanie popiołów z biomasy w górnictwie [37].

Tabela 4. Skład wyciągów wodnych z popiołów lotnych według Uliasz-Bocheńczuk i wsp. [36]

Table 4. Composition of aqueous extract from fly ashes according to Uliasz-Bocheńczuk et al. [36]

\begin{tabular}{|c|c|c|c|}
\hline \multirow{2}{*}{ Jony } & \multicolumn{3}{|c|}{ Wymywalność $\left[\mathbf{m g} / \mathbf{d m}^{\mathbf{3}}\right]$} \\
\cline { 2 - 4 } & Popiół z węgla kamiennego & Popiół z węgla brunatnego & Popiół z biomasy \\
\hline $\mathrm{Na}^{+}$ & 35,58 & 58,48 & 217,00 \\
\hline $\mathrm{K}^{+}$ & 24,10 & 51,94 & 15480,00 \\
\hline $\mathrm{Zn}^{2+}$ & 0,0010 & 0,0010 & 0,0010 \\
\hline $\mathrm{Cu}^{2+}$ & 0,0016 & 0,0018 & 0,0001 \\
\hline $\mathrm{Ni}^{2+}$ & 0,00010 & 0,0018 & 0,00051 \\
\hline $\mathrm{Pb}^{2+}$ & 0,0002 & 0,0001 & 0,0001 \\
\hline $\mathrm{Hg}^{2+}$ & 0,0011 & 0,003 & 0,0007 \\
\hline $\mathrm{Cd}^{2+}$ & 0,00024 & 0,00072 & 0,00023 \\
\hline $\mathrm{Cr}^{2+}$ & 0,038 & 0,028 & 1,587 \\
\hline $\mathrm{As}^{3+}$ & 0,0048 & 0,0064 & 0,0025 \\
\hline $\mathrm{Cl}^{-}$ & 62,4 & 114,00 & 3556,00 \\
\hline $\mathrm{SO}_{4}{ }^{2-}$ & 386,30 & 1159,00 & 13680,00 \\
\hline $\mathrm{pH}$ & 9,47 & 8,62 & 10,23 \\
\hline
\end{tabular}

Wyciągi wodne z popiołów charakteryzują się podwyższoną alkalicznością, twardością oraz wysokim przewodnictwem. $(8,4 \div 105 \mathrm{mS} / \mathrm{cm})$. Wartość $\mathrm{pH}$ wyciągów wodnych z popiołów powstających ze spalania węgla mieści się w przedziale $12 \div 12,5$ [30]. Badania przeprowadzone przez Czecha i in. [5] wykazały, że popioły lotne ze spalania węgla kamiennego mają nieznacznie wyższą alka- 
liczność w porównaniu do popiołu z węgla brunatnego, co przypisuje się większemu udziałowi sodu i potasu. Wyciągi wodne z popiołów ze spalania biomasy wykazują niższe $\mathrm{pH}$, w zakresie $9,1 \div 10,2$ [11].

Popioły lotne zaliczane są do opadów zawierających substancje promieniotwórcze. Radioaktywność popiołów lotnych zależy od technologii spalania i jest niższa dla popiołów powstających w kotłach ze złożem fluidalnym. Studium literatury potwierdza niskie stężenia radionuklidów w popiołach lotnych ze spalania węgla oraz biomasy [22, 28]. Badania aktywności pierwiastków promieniotwórczych w popiołach Elektrowni Siersza w Trzebini wykazały nieznaczną aktywność radioizotopów ( $<1 \mathrm{~Bq} / \mathrm{kg}$ ) [28]. Zgodnie z polskim prawodawstwem i normami [32], popioły zawierające radioizotopy o aktywności $<10 \mathrm{~Bq} / \mathrm{kg}$ mogą być wykorzystywane w budownictwie, przemyśle ceramicznym oraz do wypełniania wyrobisk.

Popioły lotne ze spalania węgla kamiennego i brunatnego wykazują również właściwości sorpcyjne w stosunku do zanieczyszczeń [10]. Stwierdzono również pozytywny wpływ popiołów lotnych w aspekcie usuwania fosforu oraz metali ciężkich z wody i ścieków [25]. Badania przeprowadzone przez Woźniak i Seweryn [40] wykazały poziom sorpcji dla popiołu ze spalania węgla kamiennego w elektrociepłowni w Kielcach na poziomie $70 \div 80 \%$. Deponowanie popiołów na składowiskach pogarsza ich właściwości sorpcyjne, z tego względu popiół pobrany bezpośrednio z elektrofiltrów jest lepszym sorbentem zanieczyszczeń $[9,40]$.

Materiały pyliste, w tym również popioły lotne przyczyniają się do poprawy właściwości sedymentacyjnych osadu czynnego. Dawkowanie popiołu lotnego do osadu czynnego skutkuje intensyfikacją procesu sedymentacji, znacznym obniżeniem indeksu osadu czynnego oraz poprawą jakości sklarowanych ścieków [21].

\section{Oddziaływanie popiołów lotnych na proces odwadniania osadów ściekowych}

Popioły lotne ze względu na swoje właściwości sorpcyjne wykazują wysoką skuteczną w procesach przeróbki osadów ściekowych, zwłaszcza poprzez zintensyfikowanie skuteczności procesu odwadniania. Brak kondycjonowania osadów ściekowych przed procesem mechanicznego odwadniania powoduje, że zgodnie z prawami elektrostatyki cząstki osadu obdarzone ujemnym ładunkiem elektrycznym tworzą stabilny układ, o słabej zdolności do aglomeracji, sedymentacji i podatności na odwadnianie. Po procesie kondycjonowania popiołem lotnym, cząstki osadu ulegają neutralizacji i łączą się ze sobą, co skutkuje poprawą właściwości sedymentacyjnych i odwadniających osadów ściekowych.

Pozytywny wpływ kondycjonowania popiołem lotnym na procesy odwadniania potwierdziły rezultaty badań laboratoryjnych, przeprowadzone przez licznych autorów. Eye i Basu [7] przeprowadzili badania zdolności filtracyjnych 
mieszaniny ustabilizowanego osadu ściekowego (12\% suchej masy) i popiołu lotnego przy ciśnieniu 0,2 MPa przy różnych stosunkach wagowych popiołu lotnego do osadów ściekowych. Wyniki badań potwierdziły poprawę zdolności filtracyjnych osadów ściekowych wraz ze wzrastającą dawką popiołu lotnego (tabela 5). Badając czas potrzebny do uzyskania $50 \mathrm{~cm}^{3}$ filtratu, najszybciej wymaganą ilość cieczy osadowej osiągnięto dla stosunku wagowego popiołu lotnego do osadu ściekowego 1:3 i 1:4, w związku z tym powyższe dawki uznano za optymalne. Stosując wspomniane ilości popiołu, zmniejszono uwodnienie osadów o około $53 \%$ w porównaniu do osadu surowego. Dla porównania, w przypadku odwadniania osadu niekondycjonowanego uwodnienie zmalało o około 33\%, co wskazuje na wysoką skuteczność popiołów w aspekcie poprawy odwadnialności osadów ściekowych. Wyniki przeprowadzonych badań kondycjonowania osadów ściekowych popiołem lotnym naukowcy porównali z wynikami kondycjonowania osadów samym wapnem palonym. Wprawdzie $\mathrm{CaO}$ wykazało większą skuteczność w skróceniu czasu filtracji osadów ściekowych (76 $\mathrm{cm}^{3}$ filtratu w czasie 210 sekund), ale wstępne kondycjonowanie osadów popiołem lotnym pozwoliło zastosować mniejszą dawkę wapna, obniżając koszty całego procesu [7].

Tabela 5. Rezultaty kondycjonowania osadów ściekowych popiołem lotnym według Eye i Basu [7]

Table 5. The results of sewage sludge conditioning with fly ashes according to Eye and Basu [7]

\begin{tabular}{|l|c|c|c|c|c|c|c|c|c|c|c|}
\hline \multicolumn{10}{|c|}{ Dawka popiołu [g/100 $\left.\mathbf{~ c m}^{3}\right]$} \\
\hline & $\mathbf{0}$ & $\mathbf{5}$ & $\mathbf{7 , 5}$ & $\mathbf{1 0}$ & $\mathbf{1 5}$ & $\mathbf{1 7 , 5}$ & $\mathbf{2 0}$ & $\mathbf{2 5}$ & $\mathbf{3 0}$ & $\mathbf{3 5}$ & $\mathbf{4 0}$ \\
\hline $\begin{array}{l}\text { Czas uzyskania } \\
50 \mathrm{~cm}^{3} \text { filtratu [s] }\end{array}$ & 1630 & 1302 & 1200 & 1105 & 855 & 705 & 630 & 550 & 580 & 685 & 748 \\
\hline $\begin{array}{l}\text { Uwodnienie } \\
\text { osadu [\%] }\end{array}$ & 59 & 53,5 & 50,2 & 47,5 & 46,5 & 44,3 & 42,3 & 41,3 & 40,2 & 38 & 37 \\
\hline
\end{tabular}

Badania laboratoryjne dotyczące wpływu popiołów lotnych w aspekcie zintensyfikowania procesu odwadniania osadów ściekowych przeprowadzili również Zheng i Haifeng [41]. W swoich badaniach zastosowali surowy popiół lotny oraz popiół lotny modyfikowany kwasem siarkowym w ilościach: 91\%, 273\%, $455 \%, 636 \%, 818 \%$ i $1000 \%$ masy osadów ściekowych. Badania wykazały, że wzrastająca dawka popiołu skutkuje obniżeniem oporu właściwego filtracji. Najlepsze efekty uzyskano dla osadów ściekowych kondycjonowanych popiołem modyfikowanym kwasem siarkowym o stężeniu 4 mole/ $\mathrm{dm}^{3}$ przy stosunku kwasu do popiołu równym $5: 1 \mathrm{~cm}^{3} / \mathrm{g}$. Przykładowo, w przypadku kondycjonowania surowym i modyfikowanym popiołem przy dawce $0,91 \mathrm{~g}$ popiołu $/ 1 \mathrm{~g}$ osadu, opór właściwy filtracji zmniejszył się odpowiednio o $57,6 \%$ i $89,9 \%$, przy początkowej wartości równej $1,86 \cdot 10^{13} \mathrm{~m} / \mathrm{kg}$ (rys.4). Uzyskane wyniki badań wykazały, że dalszy wzrost dawki popiołu powyżej $273 \%$ masy osadów spowodował tylko niewielkie zmiany oporu właściwego filtracji wraz ze wzrostem dawki popiołu lotnego. 
Kondycjonowanie osadów ściekowych popiołem lotnym przed procesem filtracji pozwala zmniejszyć uwodnienie placka osadowego. Zheng i Haifeng [41] w badaniach wykazali, że dawka popiołu modyfikowanego kwasem siarkowym w ilości $2,73 \mathrm{~g} / 1 \mathrm{~g}$ s.m. osadu pozwoliła zmniejszyć uwodnienie placka filtracyjnego z $86,90 \%$ (surowy osad) do 62,61\% (osad kondycjonowany) (rys. 4-5). Również prędkość filtracji znacząco zwiększyła się poprzez kondycjonowanie osadów popiołem lotnym. W celu uzyskania $60 \mathrm{~cm}^{3}$ filtratu ze $100 \mathrm{~cm}^{3}$ surowego osadu, czas trwania filtracji wynosił $300 \div 315 \mathrm{~s}$, w przypadku kondycjonowania popiołem lotnym modyfikowanym kwasem siarkowym w dawce $273 \%$ czas filtracji zmniejszył się do około 55 s [41].

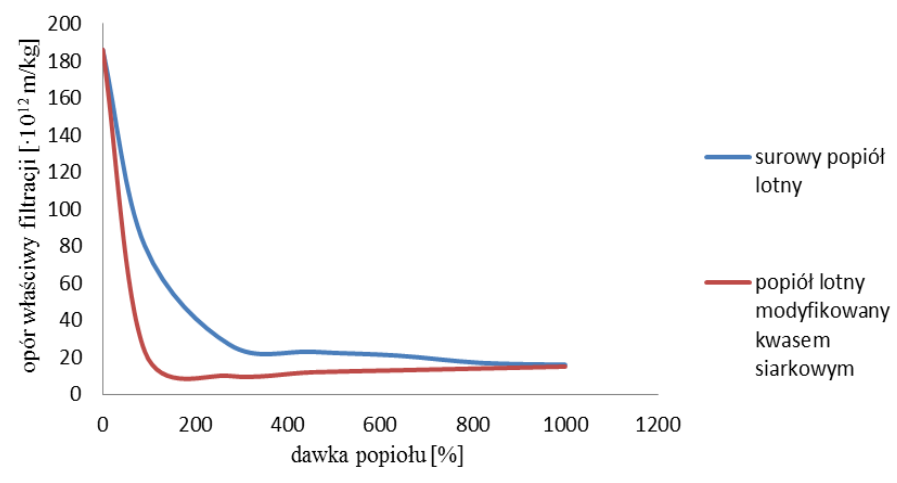

Rys. 4. Wpływ kondycjonowania popiołem lotnym na opór właściwy filtracji według Zhenga i Haifenga [41]

Fig. 4. The influence of sewage sludge conditioning with fly ashes on specific resistance to filtration according to Zheng and Haifeng [41]

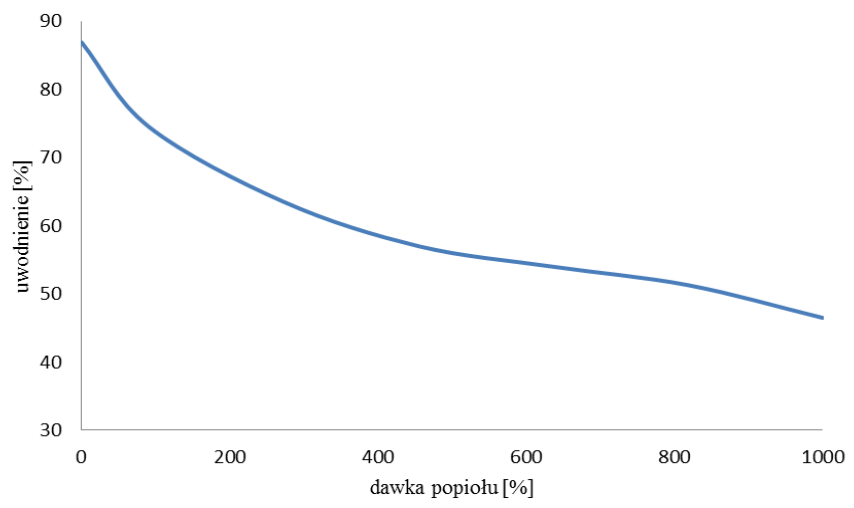

Rys. 5. Wpływ kondycjonowania popiołem lotnym na uwodnienie placka osadowego po procesie filtracji według Zhenga i Haifenga [41]

Fig. 5. The influence of sewage sludge conditioning with fly ashes on filter cake moisture according to Zheng and Haifeng [41] 
Dawkowanie popiołów lotnych do osadów ściekowych pozwala zmniejszyć ilość stosowanych polielektrolitów w procesach tzw. dualnego kondycjonowania osadów. Kuglarz i Bohdziewicz [18] przeprowadzili badania laboratoryjne nad wpływem polielektrolitów oraz mieszaniny polielektrolitów z popiołem lotnym (dawka $8 \%$ s.m.) na proces odwadniania osadów. Wprawdzie zastosowanie dualnej metody kondycjonowania nie poprawiło znacząco parametrów filtracji próżniowej w stosunku do dawkowania samych polielektrolitów, to wprowadzenie zintegrowanej metody kondycjonowania umożliwiło obniżenie dawki flokulantu o około 30\%. Skuteczność stosowania dualnego kondycjonowania osadów ściekowych określono na podstawie czasu ssania kapilarnego (CSK), oporu właściwego filtracji oraz uwodnienia (tabela 6). Najlepszą wartość oporu właściwego $\left(3,1 \cdot 10^{12} \mathrm{~m} / \mathrm{kg}\right)$ zanotowano w przypadku kondycjonowania osadów czystym polielektrolitem $\mathrm{w}$ dawce $2,5 \mathrm{mg} / \mathrm{g}$ s.m. W przypadku wstępnego kondycjonowania osadu za pomocą popiołu, podobny wynik można było osiągnąc stosując $30 \%$ mniejszą ilość polielektrolitu [18].

Tabela 6. Wpływ kondycjonowania osadów polielektrolitem i polielektrolitem z popiołem lotnym na parametry filtracyjne osadów ściekowych według Kuglarz i wsp.[18]

Table 6. The influence of sewage sludge conditioning by means of polyelectrolyte and polyelectrolyte with fly ashes on filtration parameters according to Kuglarz i wsp. [18]

\begin{tabular}{|l|c|c|c|c|c|c|c|}
\hline Dawka polielektrolitu [mg/g s.m.] & $\mathbf{0}$ & $\mathbf{0 , 5}$ & $\mathbf{1 , 0}$ & $\mathbf{1 , 5}$ & $\mathbf{2}$ & $\mathbf{2 , 5}$ & $\mathbf{3 , 0}$ \\
\hline \multicolumn{7}{|c|}{ polielektrolit kationowy } \\
\hline CSK [s] & 425 & 370 & 220 & 189 & 98 & 49 & 65 \\
\hline Opór właściwy filtracji $\left[\cdot 10^{12} \mathrm{~m} / \mathrm{kg}\right]$ & 16,2 & - & 12,2 & 10,6 & 5,7 & 3,1 & - \\
\hline Uwodnienie [\%] & 85,8 & - & 86,5 & 80,7 & 81,1 & 81,7 & - \\
\hline polielektrolit kationowy + popiół lotny (dawka 8 \% s.m.) \\
\hline CSK [s] & 340 & 210 & 146 & 44 & 57 & 39 & 52 \\
\hline Opór właściwy filtracji [·10 $\left.10^{12} \mathrm{~m} / \mathrm{kg}\right]$ & 13,1 & - & 6,9 & 1,8 & 2,8 & 2,5 & - \\
\hline Uwodnienie [\%] & 81,9 & - & 78,5 & 75,4 & 77,1 & 76,9 & - \\
\hline
\end{tabular}

\section{Wpływ popiołów lotnych na proces higienizacji osadów ściekowych}

Wyniki badań wskazują również, że popiół lotny ze względu na swoje właściwości alkalizujące oraz obecność reaktywnego $\mathrm{CaO}$ może być stosowany jako reagent do higienizacji osadów ściekowych. Dawkowanie popiołów lotnych do osadów ściekowych wywołuje szereg reakcji egzotermicznych, w wyniku czego osad ulega procesom sterylizacji, pasteryzacji i dezynfekcji [26].

Wraz ze wzrastającą dawką popiołu lotnego następuje zwiększenie wartości pH powstałej mieszaniny, co obok temperatury jest głównym czynnikiem wpływającym na destrukcję organizmów patogennych. Wzrost wartości pH osadów ściekowych po wprowadzeniu popiołu lotnego przypisuje się obecności w popiołach rozpuszczalnych tlenków, głównie $\mathrm{CaO}_{\text {i }} \mathrm{K}_{2} \mathrm{O}$ [40]. 
Popioły lotne ze względu na alkaliczne właściwości mogą stanowić alternatywę dla powszechnie stosowanego wapna $w$ procesie higienizacji osadów ściekowych. Wang i Viraraghavan [39] wykazali, że higienizacja osadów ściekowych popiołem lotnym z elektrociepłowni pozwala osiągnąc stopień redukcji mikroorganizmów chorobotwórczych $\mathrm{w}$ granicach $93 \div 100 \% \mathrm{w}$ zależności od dawki popiołu i czasu mieszania, przy początkowej populacji mikroorganizmów równej 3,76 $10^{7} \mathrm{jtk} / 100 \mathrm{~cm}^{3} \mathrm{i} \mathrm{pH}$ równym 7,25 (tabela 7).

Wpływ kondycjonowania osadów ściekowych popiołem na procesy higienizacji osadów ściekowych potwierdziły również inne badania [15]. Osiągnięto $100 \%$ redukcji bakterii coli typu kałowego po 24-godzinnym wymieszaniu popiołu lotnego z komunalnymi osadami ściekowymi, przy stosunku popiołu lotnego do osadów równym: 1:1, 1:2 i 1:3. Stopień redukcji 100\% uzyskano po 24 godzinach mieszania dla wszystkich zastosowanych dawek popiołu lotnego, przy czym dawka 1:1 skutkowała prawie natychmiastową destrukcją mikroorganizmów [16].

Tabela 7. Wpływ dawki popiołu lotnego na redukcję mikroorganizmów osadu ściekowego według Wanga i Viraraghavana [39]

Table 7. The influence of fly ash on the pathogens reduction in sewage sludge according to Wang and Viraraghavan [39]

\begin{tabular}{|c|c|c|c|c|}
\hline $\begin{array}{c}\text { Stosunek popiołów lot- } \\
\text { nych do osadów [g/ml] }\end{array}$ & $\begin{array}{c}\text { Czas miesza- } \\
\text { nia[h] }\end{array}$ & $\mathbf{p H}$ & $\begin{array}{c}\text { Ilość mikroorganizmów } \\
\text { [jtk/100ml] }\end{array}$ & $\begin{array}{c}\text { Stopień re- } \\
\text { dukcji [\%] }\end{array}$ \\
\hline 0 & - & 7,25 & $3,76 \cdot 10^{7}$ & - \\
\hline $1: 1$ & 24 & 10,30 & $1,30 \cdot 10^{4}$ & 99,97 \\
\hline $1: 3$ & 24 & 9,40 & $4,51 \cdot 10^{4}$ & 99,88 \\
\hline $1: 9$ & 24 & 8,50 & $2,35 \cdot 10^{6}$ & 93,75 \\
\hline
\end{tabular}

\section{Analiza ekonomiczna stosowania popiołów lotnych w procesach odwadniania osadów ściekowych}

Popiół lotny ze spalania paliw stanowi problemowy odpad dla wielu elektrociepłowni i pomimo poszukiwania nowych metod recyklingu, dominującym sposobem unieszkodliwiania popiołu jest nadal składowanie. Specyficzne właściwości sorpcyjne i pozytywny wpływ na procesy przeróbki osadów ściekowych powoduje, że popiół lotny jest alternatywnym rozwiązaniem dla popularnych polielektrolitów i wapna w procesach kondycjonowania i higienizacji. Za zastosowaniem popiołów w procesach przeróbki osadów ściekowych przemawia również fakt, że popiół lotny jest skutecznym, tanim i powszechnie dostępnym odpadem na terenach przemysłowych. Przykładowy kosztorys kondycjonowania osadów ściekowych za pomocą popiołu i innych reagentów przedstawili Wang i Viraraghavan [39]. Orientacyjną analizę ekonomiczną przeprowadzono dla oczyszczalni ścieków w Mill Creek w USA, z uwzględnieniem wyłącznie kosztów stosowania wybranych reagentów (tabela 8). 
Tabela 8. Analiza ekonomiczna kondycjonowania osadów ściekowych różnymi substancjami według Wanga i Viraraghavana [39]

Table 8 . The economic analysis of sewage sludge conditioning with different substances according to Wang and Viraraghavan [39]

\begin{tabular}{|c|c|c|c|c|c|}
\hline $\begin{array}{c}\text { Rodzaj } \\
\text { substancji }\end{array}$ & $\begin{array}{c}\text { Ilość suchej } \\
\text { masy w osa- } \\
\text { dach [t/dzień] }\end{array}$ & $\begin{array}{c}\text { Dawka rea- } \\
\text { genta } \\
{[\% \text { s.m.] }}\end{array}$ & $\begin{array}{c}\text { Dawka reagenta } \\
\text { [kg/dzień] }\end{array}$ & $\begin{array}{c}\text { Koszt reagenta } \\
{[\$ / \text { rok }]}\end{array}$ & $\begin{array}{l}\text { Koszt reagen- } \\
\text { ta [PLN/rok] }\end{array}$ \\
\hline \multicolumn{6}{|c|}{ kondycjonowanie wapnem i $\mathrm{FeCl}_{3}$} \\
\hline $\mathrm{CaO}$ & 1,25 & 10 & 125 & 1915 & 7660 \\
\hline $\mathrm{FeCl}_{3}$ & 1,25 & 2 & 22,7 & 2260 & 9040 \\
\hline \multicolumn{4}{|r|}{ RAZEM } & 4175 & 16700 \\
\hline \multicolumn{6}{|c|}{ kondycjonowanie wapnem i popiołem lotnym } \\
\hline $\mathrm{CaO}$ & 1,25 & 12 & 150 & 2300 & 9200 \\
\hline Popiół lotny & 1,25 & 50 & 625 & 190 & 760 \\
\hline \multicolumn{4}{|r|}{ RAZEM } & 2490 & 9960 \\
\hline \multicolumn{6}{|c|}{ kondycjonowanie wyłącznie popiołem lotnym } \\
\hline Popiół lotny & 1,25 & $25 \%$ & 3125 & 950 & 3800 \\
\hline \multicolumn{4}{|r|}{ RAZEM } & 950 & 3800 \\
\hline
\end{tabular}

Interpretacja przedstawionych wyników wykazała, że stosując wyłącznie popiół lotny w procesie kondycjonowania osadów przed mechanicznym odwadnianiem na prasie, można obniżyć koszty eksploatacyjne o $77 \%$ w porównaniu do stosowania $\mathrm{CaO}$ i $\mathrm{FeCl}_{3}$ oraz o $62 \%$ w porównaniu do kondycjonowania osadów za pomocą $\mathrm{CaO}$ i popiołu lotnego. Chociaż popiół lotny może stanowić tańszą alternatywę dla innych substancji kondycjonujących, to należy uwzględnić dodatkowe koszty związane z zakupem urządzeń do mieszania oraz dawkowania popiołu lotnego w funkcjonujących już oczyszczalniach, które stosują kondycjonowanie osadów ściekowych tradycyjnymi metodami [39].

\section{Podsumowanie}

Nadrzędna rola węgla w produkcji energii elektrycznej i cieplnej zarówno w Polsce, jak i na świecie, wymusza konieczność poszukiwania nowych metod utylizacji UPS, w tym popiołów lotnych. Rocznie na świecie powstaje około 4,2 mld ton popiołów, z czego zaledwie niewielka część jest wykorzystywana zagospodarowywana. Specyficzne właściwości popiołów lotnych oraz ich zdolności sorpcyjne powodują, że mogą one znaleźć zastosowanie w procesach przeróbki osadów ściekowych. Ze względu na swoiste cechy strukturalne, stosowanie popiołów lotnych poprawia flokulację cząstek osadu, zwiększając wielkość kłaczków. Dawkowanie popiołów lotnych do osadów przyczynia się również do neutralizacji ładunku elektrycznego osadów ściekowych.

Studium literatury potwierdza pozytywne działanie popiołów lotnych w procesach oczyszczania ścieków i przeróbki osadów ściekowych. Zastosowanie popiołów w procesie kondycjonowania osadów ściekowych przed ich me- 
chanicznym odwadnianiem powoduje obniżenie wartości czasu ssania kapilarnego oraz oporu właściwego osadu, co intensyfikuje skuteczność procesu odwadniania. Badania laboratoryjne przeprowadzone przez różnych autorów wykazały, że kondycjonowanie popiołem zwiększa efektywność odwadniania nawet o kilkadziesiąt procent $\mathrm{w}$ stosunku do osadu surowego. Popioły lotne ze spalania paliw ze względu na swój alkaliczny odczyn mogą być również z powodzeniem stosowane w procesach higienizacji osadów ściekowych, co stanowi rozwiązanie konkurencyjne dla powszechnie używanego wapna. Wyniki badań potwierdziły wysoki stopień redukcji mikroorganizmów chorobotwórczych (w granicach $93 \div 100 \%$ ) w zależności od zastosowanej dawki popiołu.

Analiza ekonomiczna stosowania popiołów w procesie kondycjonowania osadów ściekowych przed procesem odwadniania wykazała znaczne korzyści związane $\mathrm{z}$ ich stosowaniem. Zastosowanie popiołu lotnego jako substancji kondycjonującej osady pozwala obniżyć koszty eksploatacyjne o 77\% w porównaniu do stosowania wapna i $\mathrm{FeCl}_{3}$. Ze względu na fakt, że popiół lotny jest powszechnie dostępnym odpadem w elektrociepłowniach, może stanowić alternatywę dla kosztownych reagentów stosowanych w oczyszczalniach ścieków. Należy jednak zaznaczyć, że wprowadzenie nowej technologii kondycjonowania osadów ściekowych wymaga zainstalowania nowych urządzeń, m.in. do dawkowania popiołu, co wiąże się z początkowo wysokimi kosztami inwestycyjnymi. Niemniej jednak, zastosowanie popiołu lotnego w aspekcie poprawy odwadniania osadów ściekowych jest korzystnym rozwiązaniem umożliwiającym recykling dwóch problemowych frakcji odpadów. Pomimo pozytywnego wpływu popiołów na proces odwadniania i higienizacji osadów ściekowych oraz obniżenie kosztów w porównaniu do stosowania innych reagentów, metoda jak dotąd nie zyskała komercyjnego zastosowania.

\section{Literatura}

[1] Adriano D.C., Woodford T.A., Ciravolo T.G.: Utilization and disposal of fly ash and other coal residues in terrestrial ecosystems. A review., Journal of Environmental Quality, vol. 9, 1980, pp. 333-344.

[2] Ahmaruzzaman M.: A review on the utilization of fly ash, Progress in Energy and Combustion Science, vol. 36, 2010, pp. 327-363.

[3] Baliński A.: Recykling odpadowych popiołów lotnych powstających ze spalania węgla kamiennego w aspekcie wytwarzania mas formierskich, t. XLVII, z. 3, 2008, s. 5-30.

[4] Bastian S.: Betony konstrukcyjne z popiołem lotnym, Wydawnictwo Arkady, Warszawa 1980.

[5] Czech T., Sobczyk A.T., Jaworek A., Krupa A., Porównanie własności fizycznych popiołów lotnych ze spalania węgla kamiennego, brunatnego i biomasy, Materiały Konferencyjne POL- EMIS, czerwiec 2012, s. 73-82.

[6] Dudas M.J., Warren C.J.: Leaching behavior selected trace elements in chemically weathered alkaline fly-ash, Science Total Environment, vol. 76, 1988, pp. 229-246. 
[7] Eye J.D., Basu T.K.: The use of fly ash in wastewater treatment and sludge conditioning, Journal WPCF, vol. 42, no. 5, part 2, 1970, pp. 125-135.

[8] Feng Y.J., Li F., Wang X.L., Liu X.M., Zhang L.N.: Principal Chemical Properties of Artificial Soil Composed of Fly Ash and Furfural Residue, Pedosphere, vol. 16, no. 5, 2006, pp.668-672.

[9] Głomba M.: Odpady paleniskowe jako źródło sorbentu dwutlenku siarki, Ochrona Środowiska, t. 53, nr 2, 1994, s. 19-24.

[10] Hsu T.Ch.: Adsorption of an acid dye onto coal fly ash, Fuel, vol. 87, issues 13-14, 2008, pp. 3040-3045.

[11] http://www.globenergia.pl/wykorzystanie-popiolow-ze-spalania-biomasy ～(dostęp: 22.09.2016 r.).

[12] http://www.swiatbetonu.pl (dostęp: 22.09.2016 r.).

[13] http://www.wnp.pl/pliki/3943_225056.html (dostęp: 22.09.2016 r.).

[14] Jala S., Goyal D.: Fly ash as a soil ameliorant for improving crop productiona review, Bioresource Technology, vol. 97, no. 9, 2006, pp. 1136-1147.

[15] Jędrusik M., Świerczok A.: Ograniczenie emisji rtęci z procesów spalania węgla. Materiały konferencyjne: Współczesne osiągnięcia w ochronie powietrza atmosferycznego, Wydawnictwo PZITS 2010, s. 135-144.

[16] Kincannon D.F. et al.: Some effects of western coal fly ash on municipal sewage sludge, Proceeding of the Fifth International Ash Utilization Symposium, Atlanta 1979.

[17] Koukouzas N.K., Vassilatos Ch., Glarakis I.: Mixture of Lignite Fly Ash in Concrete: Physical and Mineralogical Characterization - Case Study from Ptolemais, Northern Greece, World of Fly Ash, 11-15 April 2005, Lexington, Kentucky, USA.

[18] Kuglarz M., Bohdziewicz J., Przywara L.: The influence of dual conditioning methods on sludge dewatering properties, Architecture Civil Engineering Environment, vol.1, no. 3, 2008, pp. 103-106.

[19] Lopareva-Pohu A. i wsp.: Influence of fly ash aided phytostabilisation of $\mathrm{Pb}, \mathrm{Cd}$ and $\mathrm{Zn}$ highly contaminated soils on Lolium perenne and Trifolium repens metal transfer and physiological stress, Environmental Pollution, vol. 159, no. 6, 2011, pp. 1721-1729.

[20] Małolepszy J., Wons W.: Wpływ właściwości fizykochemicznych popiołów lotnych z węgla kamiennego na procesy zachodzące podczas ich spiekania, VI Konferencja Polskiego Towarzystwa Ceramicznego Zakopane, 13-16 września 2007.

[21] Masłoń A., Tomaszek J.A. , Opaliński I.: Badania nad poprawą właściwości sedymentacyjnych osadu czynnego przy zastosowaniu mineralnych substancji pylistych, Gaz, Woda i Technika Sanitarna, nr 12, 2013, s. 490-495.

[22] Olkuski T., Stala-Szlugaj K.: Pierwiastki promieniotwórcze w węglu oraz w produktach odpadowych powstających podczas jego spalania, Środkowo- Pomorskie Towarzystwo Naukowe Ochrony Środowiska, t.11, 2009, s. 913-922.

[23] Page A.L.: Separation technologies for sludge dewatering, Journal of Hazardous Materials, vol. 144, 2007, pp. 614-619.

[24] Pandey V.C., Singh N.: Impact of fly ash incorporation in soil systems, Agriculture, Ecosystems \& Environment, vol. 136, no. 1, 2010, pp. 16-27. 
[25] Polowczyk, I. Bastrzyk, A. Sawiński, W. Koźlecki, T. Rudnicki, P. Sadowski, Z. Sokołowski, A. : Właściwości sorpcyjne popiołów ze spalania węgla, Inżynieria i aparatura chemiczna, t. 49, nr 1, 2010, s. 93-94.

[26] Poluszyńska J.: Możliwości zastosowania popiołów ze spalania biomasy w gospodarowaniu osadami ściekowymi, Prace Instytutu Ceramiki i Materiałów Budowlanych, nr 13, 2013, s. 49-59.

[27] Przekopowska M.: Prawo zapomniało o odpadach ze spalania biomasy!, Materiały seminarium "Zagospodarowanie produktów ubocznych spalania biomasy", Częstochowa 20- 21 kwietnia $2011 \mathrm{r}$.

[28] Raport z badań popiołu lotnego z elektrowni Siersza, dostępny pod adresem: http://www.anmira.pl/pliki/Badania\%20popio\%C5\%82u\%20lotnego\%20z\%20\%20El ektrowni\%20Siersza.pdf (dostęp: 22.09.2016 r.).

[29] Riehl, F., Elsass, J., Duplay, F., Huber, M., Trautmann, M.: Changes in soil properties in a fluvisol (calcaric) amended with coal fly ash, Geoderma 2010, pp. 67-74.

[30] Rosik-Dulewska C., Karwaczyńska U.: Metody ługowania zanieczyszczeń z odpadów mineralnych $\mathrm{w}$ aspekcie możliwości ich zastosowania w budownictwie hydrotechnicznym, Środkowo- Pomorskie Towarzystwo Naukowe Ochrony Środowiska, t.10, 2008, s. 205-219.

[31] Rosik-Dulewska C.: Podręcznik gospodarki odpadami, Wydawnictwo Naukowe PWN, Warszawa, 2012.

[32] Rozporządzenie Rady Ministrów z dnia 2 stycznia 2007 r. w sprawie wymagań dotyczących zawartości naturalnych izotopów promieniotwórczych potasu K-40, radu Ra226 i toru Th-228 w surowcach i materiałach stosowanych w budynkach przeznaczonych na pobyt ludzi i inwentarza żywego, a także w odpadach przemysłowych stosowanych w budownictwie, oraz kontroli zawartości tych izotopów [Dz.U. 2007 nr 4 poz. 29].

[33] Rozporządzenie Ministra Środowiska z dnia 9 grudnia 2014 r. w sprawie katalogu odpadów [Dz. U. 2014 poz.1923].

[34] Stoch A.: Fly ash from coal combustion- characterization, Praca doktorska 2015.

[35] Tripathi R.C., Jha S.K., Ram L.C.: Impact of fly ash application on trace metal content in some root crops, Energy sources, Part A: Recovery, Utilization, and Environmental Effects, vol. 32, issue 6, 2010, pp. 576-589.

[36] Uliasz- Bocheńczuk A., Pawluk A., Sierka J.:Wymywalność zanieczyszczeń z popiołów lotnych ze spalania biomasy, Gospodarka Surowcami Mineralnymi, t. 31, z. 3, 2015, s. 145-156.

[37] Vassilev et al.: An overview of the composition and application of biomass ash. Part 2. Potential utilisation, technological and ecological advantages and challenges, Fuel, vol. 105, 2013, pp. 19-39.

[38] Wacławowicz R.: Rolnicze wykorzystanie popiołów ze spalania biomasy, http:// www.scc.com.pl (dostęp: 9 września 2016 r.).

[39] Wang S., Viraraghavan T.: Wastewater sludge conditioning by fly ash, Waste Management, vol. 17, 1997, pp. 443-450.

[40] Woźniak M., Seweryn A.: Właściwości sorpcyjne modyfikowanych popiołów z węgla kamiennego, Gospodarka Surowcami Mineralnymi, t. 24, nr 3, 2008, s. 339-346. 
[41] Zheng P., Haifeng L.: Sewage sludge conditioning with coal fly ash modified by sulfuric acid, The Chemical Engineering Journal, vol. 156, no. 3, 2010, pp. 616-622.

\section{THE POSSIBILITY OF THE APPLICATION OF FLY ASHES IN ORDER TO THE IMPROVEMENT OF SEWAGE SLUDGE DEWATERING}

\section{S u m m a r y}

The growth of energy consumption is associated with fuel combustion, particularly coal. The main problem is the production of coal combustion products, particularly fly ashes. In Poland, there is produced about 4200 tons of ashes every year. Only several percent of produced ash is recycled, especially in construction industry. Stringent requirements concerning the application of ashes in many sectors of economy require new ash utilization methods in line with law and environmental requirements. Chemical composition and sorptive properties of ashes enable their application in sewage sludge conditioning. Due to the specific characteristics, fly ashes can improve the effectiveness of sewage sludge dewatering and hygienisation.

This article presents the literature review of physical and chemical properties of ashes. The article also shows the positive impact of ashes on the sewage sludge moisture content and the microbiological composition of sewage sludge. This paper also contains the economic analysis of using fly ashes in sewage sludge treatment. The application of fly ashes in treatment plants is a new solution in sewage sludge treatment.

Keywords: sewage sludge, fly ash, sewage sludge dewatering, sewage sludge conditioning, recycling, utilization, sewage sludge management

Przestano do redakcji: 01.11.2016 r.

Przyjęto do druku: 31.03.2017 r. 